\title{
ORIGIN OF MICROAGGREGATES IN SOILS WITH FERRALIC HORIZONS
}

\author{
Miguel Cooper ${ }^{1 *}$; Pablo Vidal-Torrado'; Vincent Chaplot ${ }^{2}$ \\ ${ }^{I}$ USP/ESALQ - Depto. de Solo s e Nutrição de Plantas, C.P. 9 - 13418-900 - Piracicaba, SP - Brasil. \\ IRD - Ambassade de France, BP 06, Vientiane, RPD Laos. \\ *Corresponding author <mcooper@esalq.usp.br>
}

\begin{abstract}
Microaggregates that characterize ferralic soils have been hypothesized to have physical, geochemical and/or biological origins. Despite of many studies, the hierarchy between these processes that form microaggregates has seldom been reported. The objective of this work was to study the genesis of microaggregates in a sequence of Ferralic Nitisols developed on Quaternary red clayey sediments and diabase in Piracicaba (SP), Brazil. This issue was tackled by combining optical microscopy, image analysis, scanning electron microscopy and elemental iron quantifications by X-ray fluorescence. Micromorphological investigations showed three different types of microaggregates: (i) oval microaggregates with well sorted quartz grains in their interior; (ii) oval microaggregates without or with poorly sorted quartz grains in their interior; and (iii) dense polyedric microaggregates. These morphological evidences, together with the elemental iron determinations and scanning electron microscopy, revealed the contribution of more than one process for microaggregate formation: (i) the mechanical action of the mesofauna would form the first type of microaggregates (ii) geochemical and biological processes would form the second type and (iii) the fissuration of the soil matrix by expansion and compression processes would form the third type.

Key words: Nitisol, soil genesis, micromorphology, scanning electron microscopy
\end{abstract}

\section{ORIGEM DOS MICROAGREGADOS EM SOLOS COM HORIZONTE B LATOSSÓLICO}

\begin{abstract}
RESUMO: Os microagregados, característicos do horizonte B latossólico, podem ser formados a partir de processos físicos, geoquímicos e biológicos. Apesar da quantidade de trabalhos realizados sobre este tema, poucos tem discutido a hierarquia entre os processos que formam estes microagregados. O objetivo deste trabalho foi estudar a gênese dos microagregados numa seqüência de solos localizada em Piracicaba (SP), Brasil. Os solos foram classificados como Nitossolos Vermelhos Eutroférricos latossólicos e desenvolvem-se a partir de sedimentos argilosos vermelhos do Quaternário e diabásio. Para atingir o objetivo deste trabalho foram utilizadas técnicas de microscopia ótica, análise de imagens, microscopia eletrônica de varredura e quantificações elementares de ferro através de fluorescência de raio-X. As investigações micromorfológicas mostraram a presença de três tipos de microagregados: (i) microagregados ovais com grãos de quartzo bem selecionados no seu interior; (ii) microagregados ovais sem grãos de quartzo ou grãos de quartzo mal selecionados no seu interior; e (iii) microagregados poliédricos densos. Estas evidencias morfológicas junto com os dados elementares de ferro e a microscopia eletrônica de varredura mostraram a contribuição de mais de um processo na formação dos microagregados: (i) a ação mecânica da mesofauna seria responsável pela formação do primeiro tipo de microagregados; (ii) processos geoquímicos e biológicos estariam formando o segundo tipo de microagregados; e (iii) a fissuração da matriz do solo por processos de contração e expansão formariam o terceiro tipo de microagregados.

Palavras-chave: Nitossolo, gênese de solos, micromorfologia, microscopia eletrônica de varredura
\end{abstract}

\section{INTRODUCTION}

The ferralic horizon is the diagnostic subsurface horizon of the Ferralsols and sometimes appears in some soils together with an argic or nitic horizon. Ferralic horizons are very homogeneous and morphologically show a massive structure or, in clayey materials, a weak blocky structure that breaks up into very stable microaggregates. They are highly weathered horizons with low weatherable minerals content in the sand and silt fractions (Buol \&
Eswaran, 1978). The clay fraction is a mixture of kaolinite and iron or aluminum hydroxides (ISSS-ISRIC-FAO, 1998). Most of the soils with Ferralic horizons are distributed in the tropical region, generally located on relatively stable upland summit positions or on preserved pediments or alluvial terraces. This distribution along slopes can be independent of the present rainfall regimes, suggesting a pre-weathering of the parent material.

Microaggregates, which are the characteristic elements of Ferralic horizons, may exhibit various shapes. 
They can be rounded, oval or polyedric. The shape of the microaggregates is strongly related to the processes that lead to their formation. Consequently, the formation of the microaggregate structure can be considered complex due to the existence of various hypotheses that may explain their formation and shape. Among them, a biological origin of microaggregates (Stoops, 1983; Eschenbrenner, 1986; Miklós, 1992; Vidal-Torrado, 1994), a geochemical origin (Chauvel et al., 1978; Cambier, 1986; Pedro, 1987; Santos et al., 1989) and finally a physical origin by fragmentation (Muller, 1977; Trapnell \& Webster, 1986) may be involved.

Despite numerous studies, the hierarchy between these different processes under natural conditions was seldom reported and various questions still remain for tropical soil genesis. In this context, the objective of this study was to characterize and understand the genesis of the microaggregates in the Ferralic horizons observed in the study area.

\section{MATERIAL AND METHODS}

The study area is located in Piracicaba, SP, Brazil $\left(22^{\circ} 44^{\prime} \mathrm{S}, 47^{\circ} 33^{\prime} \mathrm{W}\right)$. The study was conducted on the summit and shoulder segments of a toposequence underlayed by a Cenozoic red clayey deposit and diabase (Cooper et al., 2002). Two excavated pits were used to study the origin of the microaggregates. The soils were described and sampled according to standard methods (Lemos \& Santos, 1984) and classified according to the Brazilian Soil Classification System (Embrapa, 1999) and World Reference Base (ISSS-ISRIC-FAO, 1998).

A total of twelve (12) undisturbed and oriented soil samples were collected from different horizons of profiles 1 (P1) and 2 (P2) for micromorphological studies. In profile $1(\mathrm{P} 1)$ samples were collected from the following depths: 40-56 cm (Bt1 horizon), 72-88 cm (Bt2 horizon), 88-104 cm (Bt2-Bw1 transition), 150-166 cm (Bw1 horizon), 340-356 cm (Bw2 horizon), 480-496 cm (C horizon) and 595-611 cm (Saprolite). For profile 2 (P2) the following undisturbed samples were collected: 45-61 $\mathrm{cm}$ (Bt1 horizon), 80-96 cm (Bt2 horizon), 100-116 cm (Bt2-Bw1 transition), 110-126 cm (Bw1 horizon) and 150$166 \mathrm{~cm}$ (Bw2 horizon). Thin sections were prepared according to Murphy (1986) and the micromorphological descriptions were done according to Bullock et al. (1985).

Digital images were acquired from the thin sections and impregnated blocks using a color CCD camera with a resolution of $768 \times 576$ pixels (area of $100 \mathrm{~mm}^{2}$ pixel $^{-1}$ ). Images were processed using the Noesis Visilog ${ }^{\mathbb{B}}$ image analysis software. Total porosity (tap) was calculated as the sum of the areas of all the pores divided by the total area of the field, expressed as a percentage. The pores were divided into three shape groups, i.e. rounded, elongated and irregular, using two indexes and thresholds defined in Table 1:
Table 1 - Definition of the shape classes of the pores.

\begin{tabular}{llc}
\hline \multirow{2}{*}{ Pores } & \multicolumn{2}{c}{ Shape indexes } \\
\cline { 2 - 3 } & \multicolumn{1}{c}{$I_{1}$} & $I_{2}$ \\
\hline Rounded (Roun) & $I_{1} \leq 5$ & \\
Elongated (Elon) & $5<I_{1} \leq 25$ & $\leq 2.2$ \\
Irregular (Irr) & $5<I_{1} \leq 25$ or $>25$ & $>2.2$ \\
\hline
\end{tabular}

$$
I_{1}=\frac{P^{2}}{(4 \mathrm{p} A)}
$$

where $P$ is the perimeter of the pore and $A$ its area, and:

$$
I_{2}=\frac{\frac{1}{m} \sum_{i}\left(N_{I}\right)_{i}}{\frac{1}{n} \sum_{j}\left(D_{F}\right)_{j}}
$$

where $N_{I}$ is the number of intercepts of an object in the direction $i\left(i=0^{\circ}, 45^{\circ}, 90^{\circ}\right.$ and $\left.135^{\circ}\right), D_{F}$ is the Feret diameter of an object in the direction $j\left(j=0^{\circ}\right.$ and $\left.90^{\circ}\right), m$ is number of $i$ directions and $n$ is the number of $j$ directions.

Using the same samples of the micromorphological and image analysis studies, ultra polished thin sections were made for scanning electron microscopy (SEM) studies in backscattered electrons mode. The elemental composition of the soils was analyzed using an X-ray microanalyser coupled to the SEM at various points of the polished thin sections. Elemental analyses of iron were determined by X-ray fluorescence technique with energy dispersion in $0.025 \mathrm{~m}$ discs made from sieved $(0.002 \mathrm{~m})$ deformed soil samples taken from all the horizons.

\section{RESULTS AND DISCUSSION}

The location of the two pedons, the lateral distribution of the horizons and the slope segments are shown in Figure 1. The Ferralic Nitisol (Nitossolo Vermelho Eutroférrico latossólico) (Profiles 1 and 2 (P1 and P2)) are situated on the summit. The parent materials for this soil are the Cenozoic red clayey sediments deposited during a Quaternary sedimentation event (Cooper et al., 2002) and the diabase.

The morphological descriptions and the study of the lateral geometry of the horizons showed the presence of a ferralic horizon and a nitic horizon (Table 2). These horizons show along the slope progressive lateral and vertical transitions. This results in the gradual thickening of the nitic horizon and thinning of the ferralic horizon, until the total disappearance of the ferralic horizon on the shoulder segment (Figure 1).

\section{Micromorphology}

Profile 1 (P1): The analysis of this profile showed the passage of horizons (Bt1 and Bt2) with subangular blocky aggregates (size: $0.8-8 \mathrm{~mm}$ ) to 
microgranular structure horizons (Bw1 and Bw2). The transition between the $\mathrm{Bt}$ horizons and $\mathrm{Bw} 1$ horizons is characterized by the passage of a porphyric to an enaulic related distribution. Polyconcave vughs and planar voids dominated in the first, and in the second packing voids with some vughs and planar voids dominated. The Bw1 horizon shows two zones; the predominant one occupying $80 \%$ of the thin section surface, with an enaulic re-

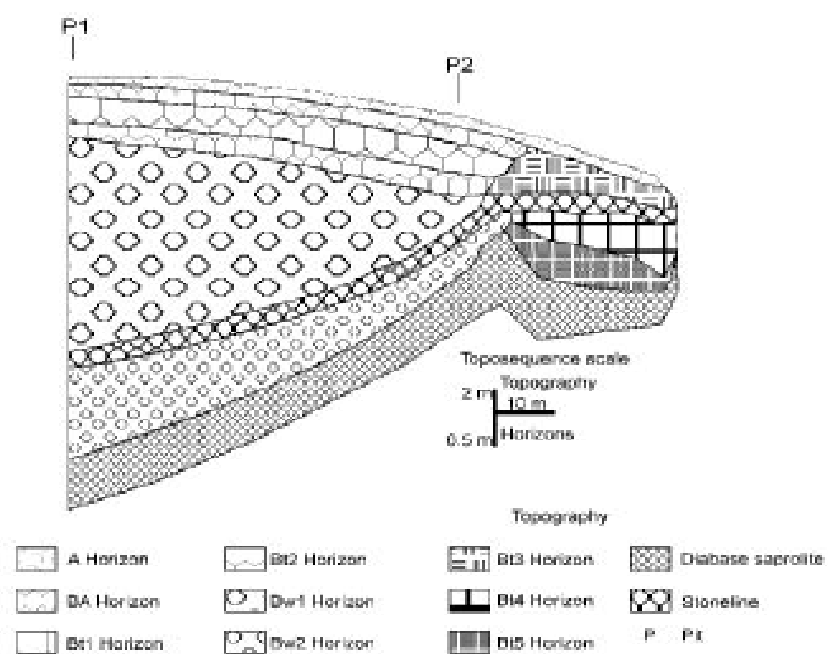

Figure 1 - Soil distribution on the toposequence. $(\mathrm{Bt}=$ nitic horizon; $\mathrm{Bw}=$ ferralic horizon). lated distribution and a microgranular microstructure (Figure 2) and the other, that occupies $20 \%$ of the thin section surface, with a closed porphyric related distribution and a subangular blocky microstructure. A similar situation to the one described above is observed in the Bw2 horizon, where the soil matrix is characterized by an enaulic related distribution with some isolated porphyric domains. A gradual transition and the inexistence of a dis-

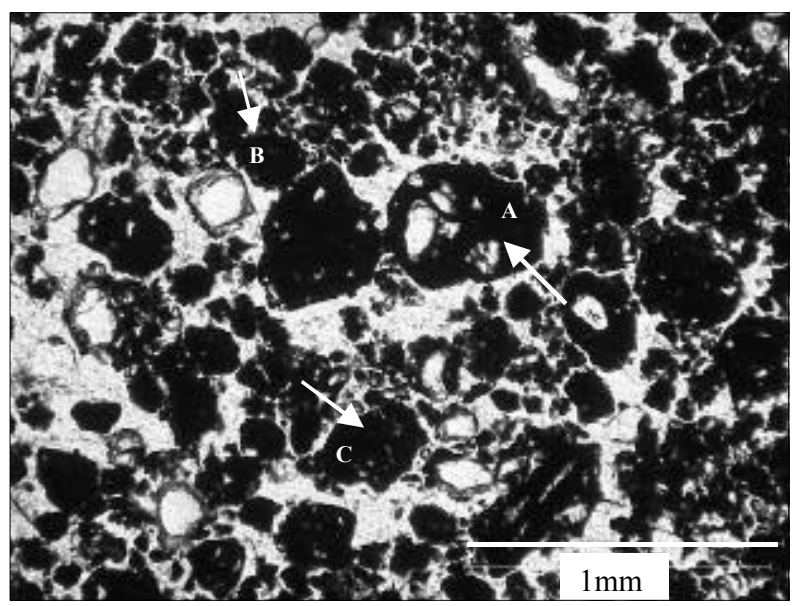

Figure 2 - Photomicrograph of the ferralic horizon showing the presence of: A) oval with well sorted quartz grains distributed in their interior (OWQ), B) oval without or with poorly sorted quartz grains distributed in their interior (ONQ), and $\mathrm{C})$ polyedric microaggregates (PM).

Table 2 - Field morphology descriptions.

\begin{tabular}{|c|c|c|c|c|c|c|}
\hline Horizon & Depth, cm & Structure* & Colour & Texture & Clay coatings** & Consistence*** \\
\hline \multicolumn{7}{|c|}{ Profile 1: (Ferralic Nitisol) } \\
\hline A & $0-10$ & $2 ; \mathrm{f} ; \mathrm{sb}$ & $5 Y R 3 / 4$ & clayey & - & $h ;$ fr \\
\hline $\mathrm{BA}$ & $10-30$ & $3 ; \mathrm{f} ; \mathrm{sb}$ & 2.5 YR $2.75 / 4$ & clayey & - & $h ; f r$ \\
\hline Bt1 & $30-70$ & $3 ; \mathrm{m} ; \mathrm{sb}$ & 2.5 YR $3.5 / 4$ & clayey & $\mathrm{co} ; \mathrm{w}$ & $h ; f r$ \\
\hline $\mathrm{Bt} 2$ & $70-90$ & $3, \mathrm{~m} ; \mathrm{sb}$ & $2.5 \mathrm{YR} 3 / 5$ & clayey & $\mathrm{f} ; \mathrm{w}$ & $h ; f r$ \\
\hline Bw1 & $90-285$ & $1 ; \mathrm{m} ; \mathrm{sb}$ & $2.5 \mathrm{YR} 4 / 6$ & clayey & - & $\mathrm{h} ; \mathrm{vfr}$ \\
\hline Stoneline & $285-300$ & - & - & - & - & - \\
\hline Bw2 & $300-465$ & $1 ; \mathrm{m} ; \mathrm{sb}$ & $2.5 Y R \quad 4 / 6$ & clayey & - & $\mathrm{h} ; \mathrm{fr}$ \\
\hline $\mathrm{C}$ & $465-580$ & - & - & - & - & - \\
\hline Saprolite & $580+$ & - & - & - & - & - \\
\hline \multicolumn{7}{|c|}{ Profile 2: (Ferralic Nitisol) } \\
\hline A & $0-16$ & $3 ; \mathrm{f} ; \mathrm{gr} ; \mathrm{sb}$ & $2.5 \mathrm{YR} 2 / 6$ & clayey & - & $\mathrm{h} ; \mathrm{fr}$ \\
\hline $\mathrm{BA}$ & $16-34$ & & & & & \\
\hline Bt1 & $34-77$ & $3 ; \mathrm{m} ; \mathrm{sb} ; \mathrm{pr}$ & $2.5 \mathrm{YR} 3 / 6$ & clayey & $a b ; s t$ & $\mathrm{~h} ; \mathrm{fr}$ \\
\hline $\mathrm{Bt} 2$ & $77-103$ & $2 ; \mathrm{m} ; \mathrm{sb} ; \mathrm{pr}$ & $2.5 \mathrm{YR} 3 / 6$ & clayey & $\mathrm{c}$ to $\mathrm{ab} ; \mathrm{m}$ & $\mathrm{h} ; \mathrm{fr}$ \\
\hline Bw1 & $103-130$ & $1 ; \mathrm{m} ; \mathrm{sb}$ & $2.5 \mathrm{YR} 3 / 6$ & clayey & $\mathrm{f} ; \mathrm{w}$ & vfr \\
\hline Stoneline & $130-142$ & - & - & - & - & - \\
\hline Bw2 & $142-179$ & $3 ; \mathrm{f}$; gr; & $2.5 \mathrm{YR} 3 / 6$ & clayey & - & vfr \\
\hline
\end{tabular}

* 3 = strong; $2=$ moderate; $1=$ weak; $\mathrm{f}=$ fine; $\mathrm{m}=$ medium; $\mathrm{gr}=$ granular; $\mathrm{sb}=$ subangular blocky; $\mathrm{pr}=$ prismatic

** $\mathrm{f}=$ few; $\mathrm{c}=$ common; $\mathrm{ab}=$ abundant; $\mathrm{w}=$ weak; $\mathrm{m}=$ moderate; $\mathrm{st}=$ strong

$* * *($ dry) $\mathrm{h}=$ hard; (humid) $\mathrm{fr}=$ friable; $\mathrm{vfr}=$ very friable

Sci. Agric. (Piracicaba, Braz.), v.62, n.3, p.256-263, May/June 2005 
tinct geometric distribution pattern were observed between these two zones in both horizons (Bw1 and Bw2).

Packing voids dominate throughout the Bw1 and Bw2 horizons together with some policoncave vughs that are found in the porphyric domains. In the enaulic domains, the microstructure of the Bw1 and Bw2 horizons is dominated by different types of microaggregates: oval microaggregates with well sorted quartz grains in their interior, oval microaggregates without or with poorly sorted quartz grains in their interior and polyedric microaggregates. Within these three types of microaggregates, the dominant types were the oval without or with poorly sorted quartz grains and polyedric. The presence of well-sorted coarse material inside the oval microaggregates of the Bw horizons, suggests a biological origin for them (Miklós, 1992). The presence of a large amount ( $20 \%$ of the surface of the thin sections) of channels and vughs of dimensions varying from 1 to 5 $\mathrm{mm}$ in diameter with loose continuous infillings and of diverse forms (elliptic, circular and tubular) evidenced the importance of the biological activity in this profile.

Two well-defined zones with a gradual transition between them were observed in the $\mathrm{C}$ horizon. One of the zones ( $25 \%$ of the thin section) is formed by an alteration matrix that presents a speckled b-fabric with a brownish to yellow-brownish color made up of altered plagioclases and kaolinite. This zone presents a porphyroenaulic related distribution and is dominated by polyconcave vughs and planar voids. The other zone ( $75 \%$ of the thin section) shows a matrix with a higher degree of alteration and is formed by red to brownishred fine material with a speckled and undifferentiated $b$ fabric. This last zone presents a porphyric and porphyroenaulic related distribution and is dominated by polyconcave and mamelonar vughs together with biological vughs, channels and planar voids. An incipient microstructure is observed in both zones and it is formed by subangular blocky aggregates and agglomerations of microaggregates.

Three distinct zones characterize the Saprolite sample. The first zone, occupying $40 \%$ of the thin sections, is characterized by an alteration matrix with conserved parent material structure; the second zone, occupying $30 \%$ of the thin section, is a transitional zone characterized by a decrease in the size of the coarse material (primary minerals) and formation of fine material (kaolinite) impregnated with iron (Fe); and finally the third zone presents a more evolved soil matrix with the development of an incipient microstructure and a diminution in the quantity of primary minerals. In the second and third zones speckled and undifferentiated b-fabrics dominate and a higher concentration of iron (Fe) is observed. The incipient microstructure of the third zone presents subangular blocky aggregates with a weakly developed pedality together with agglomerations of microaggregates. Due to the different degrees of alteration observed in this sample, many types of pores were described; among these we find polyconcave and mamelonar vughs, channels and planar voids. The related distribution in all zones was described as porphyric and the transition between the zones is gradual with no distinct geometry.

Profile 2 (P2): Up to the depth of $95 \mathrm{~cm} \mathrm{P2}$ mostly showed subangular blocky aggregates (size: 0.8 $-5 \mathrm{~mm}$ ) whereas, below this limit microaggregates (size: $0.05-1 \mathrm{~mm}$ ) predominated. The Bt horizons showed a porphyric related distribution with the predominance of vughs, channels and planar voids. The transition between the $\mathrm{Bt}$ and $\mathrm{Bw} 1$ horizons is marked by the passage of a porphyric to an enaulic related distribution where packing and planar voids dominate. The fine material is undifferentiated in practically all the profile, finding mosaicspeckled domains in the microaggregated zone of the transition between the $\mathrm{Bt} 2$ and $\mathrm{Bw} 1$ horizons. The Bw1 horizon presents a porphyro-enaulic related distribution where closely packed polyedric and oval microaggregates dominate together with some isolated subangular blocky aggregates. Contrasting with $\mathrm{Bw} 1, \mathrm{Bw} 2$ horizon presents a typical enaulic related distribution dominated by oval with well sorted quartz grains, oval without or with poorly sorted quartz grains and polyedric microaggregates separated by well developed packing voids. As in P1, the type of microaggregate that dominates in the $\mathrm{Bw}$ horizons is the oval without or with poorly sorted quartz grains in their interior. Polyedric microaggregates in the Bw horizons of both profiles (P1 and P2) presented no quartz grains or moderately to poorly sorted quartz grains in their interior. The presence of channels and vughs of various forms (elliptic, tubular and circular) with loose continuous infillings, occupying $15 \%$ of thin section surface, evidenced the intensity of the faunal activity in this soil.

\section{Image analysis}

Figure 3 shows the total area occupied by pores on the images and the distribution of these pores according to size and shape. In both horizons rounded (Roun) and irregular (Irr) pores dominate, although rounded pores were more dominant in Bw1 than Bw2, and Bw2 presented greater amount of large irregular pores. Rounded pores include channels, isolated vughs and tubular pores, and irregular pores are those highly interconnected pores between soil particles or soil aggregates, or pores that present highly contorted shapes. These quantitative results of the soil porosity agree with the micromorphological descriptions and show the predominance of a microgranular and subangular blocky microstructure with enaulic and dense porphyric areas in Bw1 and of an enaulic related distribution with a microgranular microstructure in Bw2. The predominance of rounded pores in 
both horizons helps to explain the high biological activity observed in the micromorphological descriptions and its influence on soil formation processes. Fissuration processes are more dominant in Bw2 where the elongated pores (Elon) occupy a larger proportion of the total porosity when compared to Bw1, probably evidencing the formation of polyedric microaggregates.

\section{Scanning electron microscopy}

Detailed scanning electron microscope analysis showed a particulate organization in the saprolite matrix presenting textural packing voids between coarse kaolinite particles (Figure 4a). In some areas of the saprolite, denser zones are observed (Figure $4 b$ ). These would be originated by the re-organization and densing of the particulate matrix forming a kaolinite-iron oxide system as described by Cambier (1986) (Table 3). This fine kaolinitic material is situated between the coarse kaolinitic material leading to the latter's cementation. This densification of the soil matrix is more pronounced as we ascend in the soil profile towards the pedogenetic horizons.
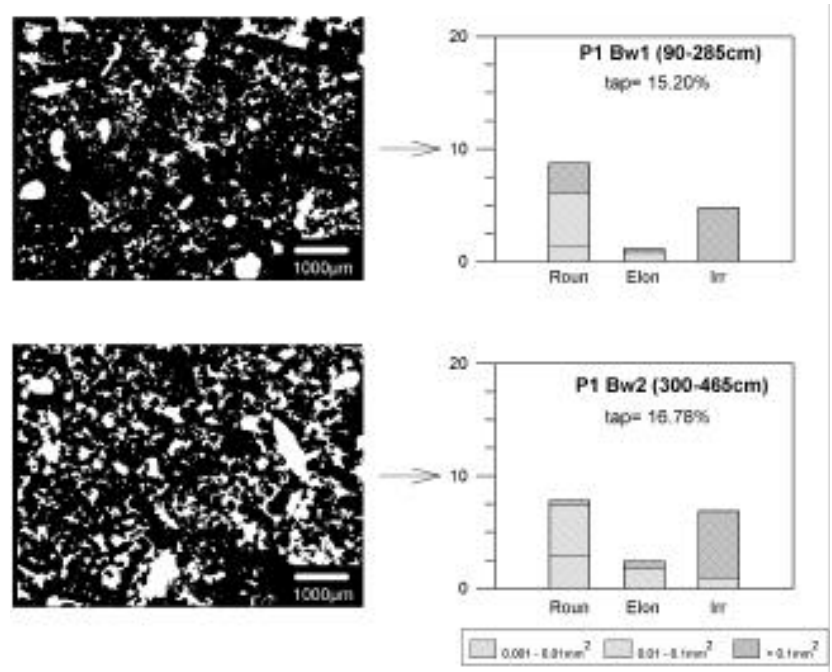

Figure 3 - Pore distribution according to area and shape and the corresponding binary images (pores appear in white and the soil matrix in black). Roun $=$ rounded, Elon $=$ elongated, Irr $=$ irregular, tap $=$ total area of pores, $\mathrm{BW}$ $=$ ferralic horizon.
The evolution of the saprolite matrix from coarse particulate to dense and massive is linked to the microaggregate formation. As the saprolite matrix suffers a densification process, a second saprolite matrix re-organization process leads to the individualization of the microaggregates forming, initially, policoncave and mamelonar voids (Figure 4c) that later evolve to compound packing voids (Figure $4 \mathrm{~d}$ ) aided by a micro-fissuration process. The result of this two-stage re-organization process is the formation of oval and dense microaggregates made up of kaolinite and iron with no coarse material or poorly sorted coarse material in their matrix.

\section{Origin of the microaggregate structure}

The microaggregate structure is characteristic of the ferralic horizons and results from the packing of microaggregates and quartz grains. Two types of microaggregates were described: oval and polyedric microaggregates (PM) (Figure 2). The oval microaggregates predominate in relation to the polyedric microaggregates in the studied ferralic horizons.

The detailed observation of the oval microaggregates permitted to divide them into two groups, those that presented well sorted quartz grains distributed in their interior (OWQ), and those that did not (ONQ) (Figure 2). A biological origin was attributed to the first group. Miklós (1992) presented five morphological characteristics that classified the oval microaggregates as originated from faunal activity. These characteristics were the oval shape of the microaggregates, size between 100 and $1000 \mathrm{~mm}$, the presence of neostrians on the periphery of the microaggregates, different colored microaggregates and well-sorted coarse material in the interior of the microaggregates. Of these, three characteristics were observed in some of the studied microaggregates. These were the oval shape of the microaggregates, the size (100 to $1000 \mathrm{~mm}$ ) and the presence of well-sorted coarse material in the interior of them.

The biological origin for these microaggregates can be explained by the oval or circular format that soil's mesofauna (ants and termites) gives to the soil material with their mandibles, when transporting material from one place to another for the construction of their nests or for

Table 3 - Elemental composition of the coarse kaolinite and fine kaolinite rich in iron.

\begin{tabular}{|c|c|c|c|c|c|c|c|c|c|c|c|c|c|c|}
\hline & $\mathrm{Na}$ & $\mathrm{Mg}$ & $\mathrm{Al}$ & $\mathrm{Si}$ & $\mathrm{P}$ & $\mathrm{S}$ & $\mathrm{Cl}$ & K & $\mathrm{Ca}$ & $\mathrm{Ti}$ & $\mathrm{Cr}$ & $\mathrm{Mn}$ & $\mathrm{Fe}$ & $\mathrm{O}$ \\
\hline & & & & & & & - & & & & & & & --.- \\
\hline Coarse Kaolinite 1 & 1 & 0 & 214 & 259 & 0 & 0 & 0 & 0 & 1 & 0 & 0 & 1 & 26 & 494 \\
\hline Coarse Kaolinite 2 & 0 & 4 & 196 & 254 & 2 & 1 & 4 & 1 & 2 & 0 & 0 & 0 & 30 & 485 \\
\hline Fine Kaolinite 1 & 0 & 0 & 165 & 245 & 4 & 0 & 24 & 1 & 6 & 5 & 2 & 0 & 82 & 467 \\
\hline Fine Kaolinte 2 & 1 & 7 & 179 & 243 & 3 & 0 & 12 & 0 & 4 & 2 & 0 & 0 & 78 & 472 \\
\hline Fine Kaolinite 3 & 0 & 0 & 186 & 252 & 3 & 0 & 17 & 2 & 4 & 0 & 1 & 0 & 55 & 479 \\
\hline
\end{tabular}

Sci. Agric. (Piracicaba, Braz.), v.62, n.3, p.256-263, May/June 2005 


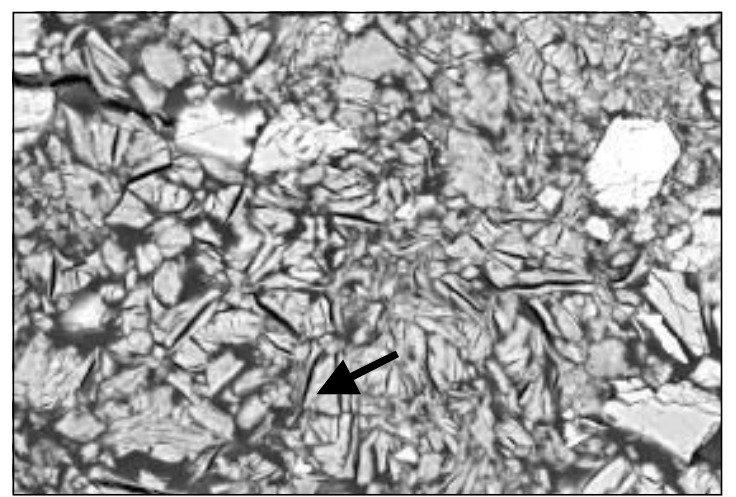

A) $20 \mu \mathrm{m}$

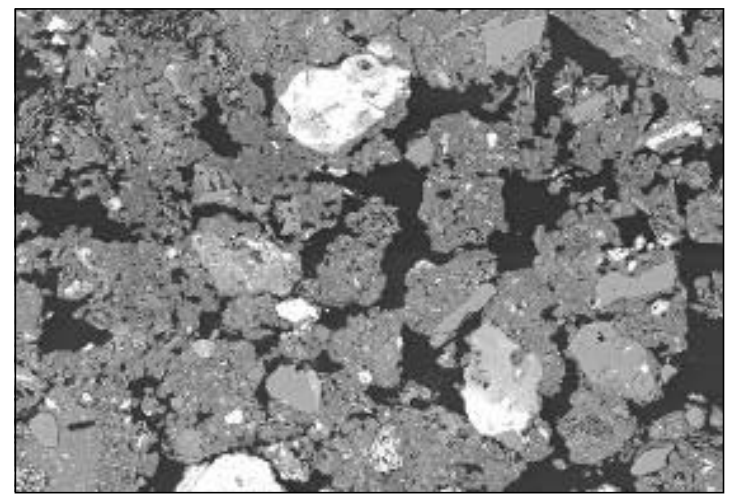

C) $100 \mu \mathrm{m}$

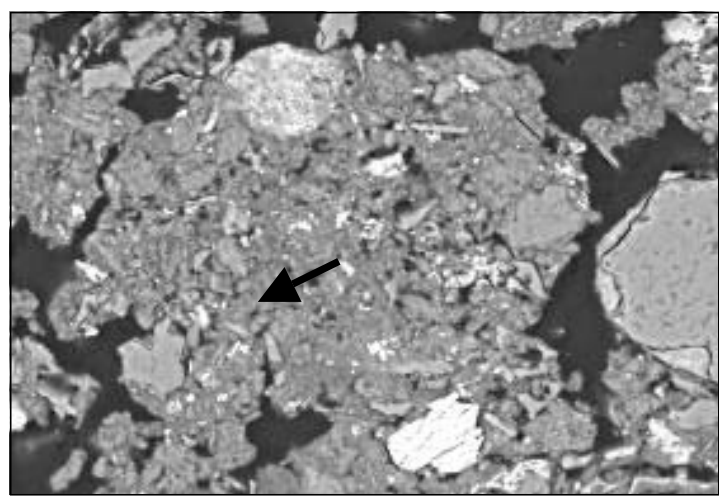

B)

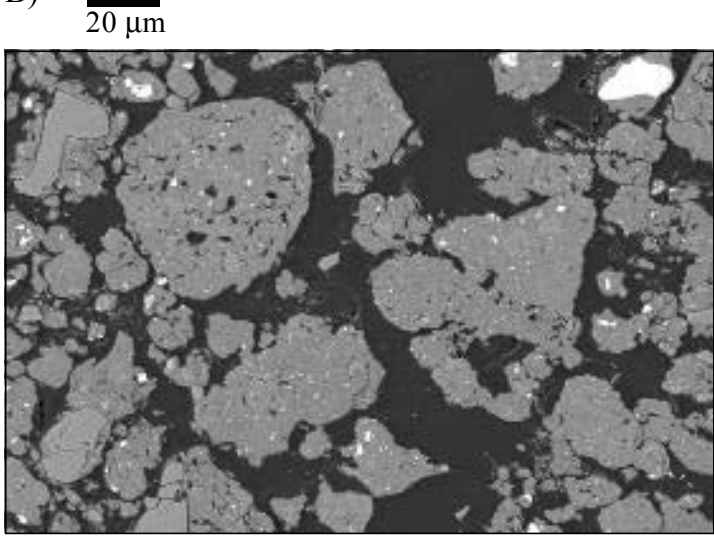

D)

\section{$100 \mu \mathrm{m}$}

Figure 4 - Scanning electron microscope images of the formation of microaggregates. A) Coarse kaolinite (arrow), B) Coarse kaolinite impregnated with fine kaolinite rich in iron (arrow), C) Microaggregate individualization in the saprolite, D) Microaggregates in the ferralic horizon.

closing unused channels. This microaggregate formation would result in the sorting of the quartz size and the formation of neostrians as reported by Eschenbrenner (1986) and Miklós (1992) that named this process as bioaggregation. The presence of neostrians was not observed in the oval microaggregates with well sorted coarse material studied in this area. This could be explained by the masking of the b-fabrics by the high iron content of these soils (Table 4).

The formation of ONQ that were observed during the micromorphological studies is uncertain and could be biological and/or geochemical. As mentioned above, the evidences shown by Miklós (1992) to define microaggregates of biological origin were not observed in the descriptions, although these could have been masked by the high iron contents of the soil and pedoturbation processes. Various hypotheses have been presented about the geochemical formation of these microaggregates. These can be formed by a simple rearrangement of the plasma (Muller, 1977) or by geochemical evolution that results from physico-chemical interactions between iron and kaolinite (Pedro et al., 1976; Chauvel et al., 1978; Cambier, 1986; Pedro, 1987; Dexter, 1988; Santos et al., 1989). The presence of a domi-
Table 4 - Elemental Fe values of samples taken from profile 1 (P1).

\begin{tabular}{lcc}
\hline Sample & Depth. & Iron \\
\hline $\mathrm{N}^{\circ}$ & $\mathrm{m}$ & $\mathrm{g} \mathrm{kg}^{-1}$ \\
01 & $0-0.1$ & 136.1 \\
02 & $0.1-0.4$ & 150.1 \\
03 & $0.4-0.67$ & 147.9 \\
04 & $0.67-1.15$ & 150.4 \\
05 & $1.15-2.35$ & 155.6 \\
06 & $2.35-2.85$ & 147.8 \\
07 & $2.85-4.65$ & 147.4 \\
08 & $4.65-4.8$ & 153.3 \\
09 & $4.8-5.8$ & 157.3 \\
10 & 6.3 & 143.5 \\
11 & 6.8 & 157.5 \\
12 & rock & 111.2 \\
\hline
\end{tabular}

nant kaolinitic clay mineralogy (Figure 4, Table 3), high iron contents in the soil matrix (Table 4) and of evidences of a kaolinite-iron oxide system (Cambier, 1986) on this toposequence suggests that part of these microaggregates could have been formed by geochemical evolution. Con- 
sequently, which ONQ are formed by biological or geochemical processes is very difficult to determine and requires more detailed studies.

The PM were the third type of microaggregates studied. They would be formed by the fissuration of the denser groundmass with a porphyric related distribution. This fissuration, evident in the micromorphological descriptions (Figure 5), would result from the expansion and contraction of the soil material due to alternated cycles of wetting and drying. The result of this intense fissuration of the porphyric groundmass is the creation of a network of planar voids isolating polyedric microaggregates (PM) that are later included into the enaulic soil matrix by pedoturbation processes. Trapnell \& Webster (1986) observed the same process of microaggregate formation, calling them fragmental aggregates.

Agreeing with what was suggested by Buol \& Eswaran (1978), Stoops (1983), Stoops \& Buol (1985) and Vidal-Torrado (1994), the microaggregates formed in the ferralic horizons showed varied shapes and various origins, result of the intervention of more than one formation process.

The result of the overall observation of the microaggregates in the studied ferralic horizon showed the predominance of ONQ. These are distributed homogeneously throughout the ferralic horizon and can be related to past and present soil forming processes. The OWQ and PM appear in the same proportion in the ferralic horizon but their distribution differs from the ONQ. The OWQ and some ONQ are concentrated in vughs and channels as loose and continuous infillings, thus located only where the faunal activity has occurred. The PM are found mainly at the transition between the nitic and ferralic horizons and the upper part of the ferralic horizon. This can be interpreted as the dismantling of the blocky structure dominant in the nitic horizon to polyedric microaggregates due to fissuration processes. This fissuration process has been accentuated af-

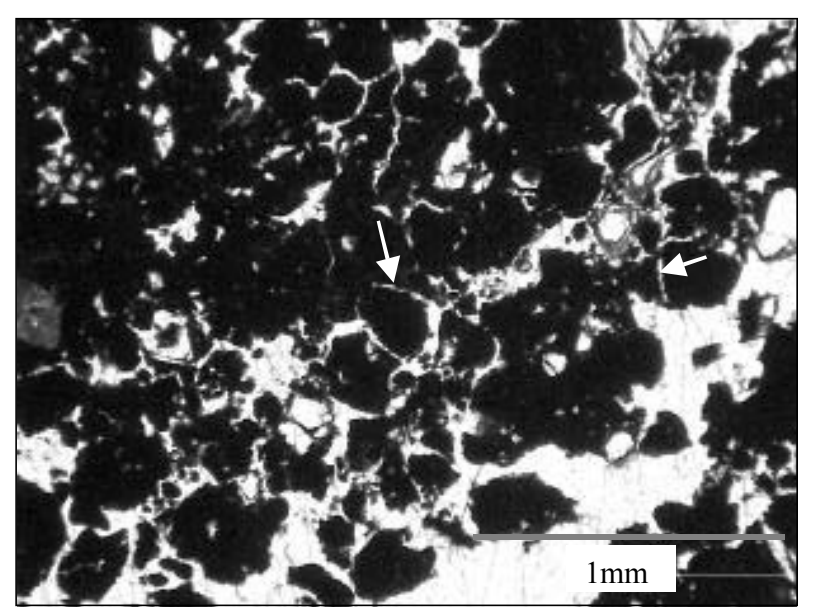

Figure 5 - Photomicrograph showing the fissuration of the porphyroenaulic related distribution (arrows). ter deforestation and the introduction of pastures. This land use substitution could have caused variations in the soil water dynamics and consequently on the soil expansion and contraction cycles which could have enhanced the fissuration process. This change in land use has also had a negative effect on biological activity, thus affecting the formation of microaggregates by biological processes.

\section{CONCLUSIONS}

The participation of more than one process in the formation of the microaggregates determined their multigenetic origin. The formation of oval with well sorted coarse material (OWQ), oval without or with poorly sorted coarse material (ONQ) and polyedric microaggregates (PM) could be the final product of biological, geochemical and fissuration processes.

Overall observations suggest that the ONQ microaggregates, with a geochemical or biological origin, dominate over the OWQ and PM microaggregates related to a biological and fragmental origin, respectively. ONQ microaggregates would present a more homogeneous distribution in the ferralic horizon whereas OWQ and PM are restricted to the locations where their formation processes occur. Processes linked to changes in land use and deforestation could have largely affected the present formation of the biological and fragmental microaggregates. More precise studies have to be undertaken to verify if the changes in land use in this study area have also affected the formation of geochemical microaggregates.

\section{ACKNOWLEDGMENTS}

To Dr. Selma Simões de Castro, for her advice during the micromorphological studies, and FAPESP for financial support.

\section{REFERENCES}

BULLOCK, P.; FEDOROFF, N.; JONGERIUS, A.; STOOPS, G.; TURSINA, T.; BABEL, U. Handbook for soil thin section description. Wolverhampton: Waine Research Publication, 1985. 152p.

BUOL, S.W.; ESWARAN, H. The micromorphology of oxisols. In: INTERNATIONAL WORKSHOP MEETING ON SOIL MICROMORPHOLOGY, 5., Granada, 1978. Proceedings. Granada: Universidad de Granada, 1978. p.325-347.

CAMBIER, P. Organisation des constituants et interactions physicochimiques au sein des microagrégats de sols. Application au système ferralitique kaolinite-oxyde de fer. Paris: Université de Paris VI, 1986. 223p. (PhD - Thesis).

CHAUVEL, A.; BOCQUIER, G.; PEDRO, G. La stabilité et la transformation de la microstructure des sols rouges ferralitiques de Casamance (Senegal). Analyse microscopique et données experimentales. In: INTERNATIONAL WORKSHOP MEETING ON SOIL MICROMORPHOLOGY, 5., Granada, 1978. Proceedings. Granada: Universidad de Granada, 1978. p.779-813.

COOPER, M.; VIDAL-TORRADO, P.; LEPSCH, I.F. Stratigraphical discontinuities, tropical landscape evolution and soil distribution relationships in a case study in SE-Brazil. Revista Brasileira de Ciência do Solo, v.26, p.673-683, 2002. 
DEXTER, A.R. Advances in characterization of soil structure. Soil and Tillage Research, v.11, p.199-238, 1988.

EMPRESA BRASILEIRA DE PESQUISA AGROPECUÁRIA Sistema brasileiro de classificação de solos. Brasília: Embrapa Produção de Informação, 1999. 396p.

ESCHENBRENNER, V. Contribution des termites à la micro-agrégation des sols tropicaux. Cahiers ORSTOM Séries Pédologie, v.22, p.397408, 1986.

ISSS-ISRIC-FAO. World reference base for soil resources. Rome: FAO, 1998. 109p.

LEMOS, R.C. de; SANTOS, R.D. dos. Manual de descrição e coleta de solo no campo. Campinas: SBCS, 1984. 46p.

MIKLÓS, A.A. DE W. Biodynamique d'une coverture pédologique dans la région de Botucatú, Brésil. Paris: Université de Paris VI, 1992. 438p. (PhD - Thesis)

MULLER, J.P. Microestruturation des structichrons rouges ferralitiques, à l'amont des modelés convexes (Centre-Cameroun). Aspects morphologiques. Cahiers ORSTOM Séries Pedologie, v.15, p.239-258, 1977.

MURPHY, C.P. Thin section preparation of soils and sediments Rothamsted: A.B. Academic Publishers, 1986. 149p.

PEDRO, G. Géochimie, mineralogie et organisation des sols. Aspects coordonnés des problèmes pédogénétiques. Cahiers Orstom Séries Pédologie, v.23, p.169-186, 1987.
PEDRO, G.; CHAUVEL, A.; MELFI, A. Recherces sur la constitution des Terra Roxa Estruturada du Brésil. Annalles Agronomie, v.27, p.265294, 1976.

SANTOS, M.C.D.; MERMUT, A.R.; RIBEIRO, M.R. Submicroscopy of clay microaggregates in an oxisol from Pernambuco, Brazil. Soil Science Society of America Journal, v.53, p.1895-1901, 1989.

STOOPS, G. Micromorphology of the oxic horizon. In: INTERNATIONAL WORKSHOP MEETING SOIL MICROMORPHOLOGY, 6., Rothamsted, 1983. Proceedings. Rothamsted: A.B. Academic Publishers, 1983, p.419-440.

STOOPS, G.; BUOL, S.W. Micromorphology of oxisols. In: DOUGLAS, L.A.; THOMPSON, M.L. (Ed.) Soil micromorphology and soil classification. Madison: SSSA, 1985. p.105-119.

TRAPNELL, C.G.; WEBSTER, R. Microaggregates in red earths and related soils in East and Central Africa, their classification and occurrence. Journal of Soil Science, v.37, p.109-123, 1986.

VIDAL-TORRADO, P. Pedogênese e morfogênese no distrito de Tupi (Piracicaba-SP). Piracicaba:USP/ESALQ, 1994. 169p. (Tese Doutorado).

Received September 24, 2004

Accepted March 10, 2005 